\title{
ASPEK HUKUM PEMERINTAHAN TERHADAP \\ PENGGUNAAN TENAGA KERJA ASING DI INDONESIA \\ DAN IMPLIKASINYA TERHADAP KEDAULATAN \\ NEGARA
}

Dodi Jaya Wardana, S.H., M.H.

Fakultas Hukum Universitas Muhammadiyah Gresik

dodijayawardana@umg.ac.id/dodiairlangga552yahoo.com

\begin{abstract}
The effectiveness and urgency of the use of foreign workers in Indonesia is very effective and urgent to meet the needs of skilled and professional workforce in certain fields that can not be occupied by local workers and as a step in accelerating the process of national and regional development by accelerating the transfer of knowledge and technology and increase foreign investment in the presence of foreign workers as supporting development in Indonesia, although in reality companies in Indonesia, whether foreign or national private companies, must use the Indonesian experts themselves. The purpose of regulating foreign workers if viewed from the aspect of labor law is basically to guarantee and provide decent employment opportunities for Indonesian citizens in various fields and levels. So that in hiring foreign workers in Indonesia must be done through strict mechanisms and procedures starting with the selection and licensing procedures to supervision.
\end{abstract}

Keywords: Legal aspects of the use of foreign workers and its implications on state sovereignment. 


\section{Latar Belakang Masalah}

Indonesia merupakan negara hukum. Demikianlah bunyi Pasal 1 ayat (3) Undang-Undang Dasar Negara Republik Indonesia Tahun 1945. Sebagai konsekuensi dari negara hukum (rechtstaat), maka seluruh kegiatan mulai dari pelaksanaan dan penyelenggaraan pemerintahan, kehidupan rakyat, perekonomian, perindustrian, investasi dan termasuk di dalamnya penggunaan tenaga kerja asing di Indonesia harus berdasarkan hukum dan bukan berdasarkan kekuasaan belaka (machtstaat). Pemerintah Indonesia, dengan pertimbangan untuk mendukung perekonomian nasional dan perluasan kesempatan kerja melalui peningkatan investasi, pemerintah memandang perlu pengaturan kembali perizinan penggunaan tenaga kerja asing. Mengingat pengaturan perizinan penggunaan tenaga kerja asing yang diatur dalam Peratuan Presiden Nomor 72 Tahun 2014 tentang Penggunaan Tenaga Kerja Asing Serta Pelaksaan Pendidikan dan Pelatihan Tenga Kerja Pendamping sudah tidak sesuai lagi dengan perkembangan kebutuhan untuk peningkatan investasi dan peningkatan perekonomian.

Atas dasar pertimbangan tersebut, pemerintah Indonesia menerbitkan Peraturan Presiden (Perpres) Nomor 20 Tahun 2018 Tentang Penggunaan Tenaga Kerja Asing di Indonesia. Dalam ketentuan Perpres tersebut disebutkan bahwa penggunaan Tenaga Kerja Asing dilakukan oleh pemberi kerja Tenaga Kerja Asing 
dalam hubungan kerja untuk jabatan tertentu dan waktu tertentu, yang dilakukan dengan memperhatikan kondisi pasar tenaga kerja dalam negeri. Dengan kondisi seperti itu, maka penggunaan dan kesempatan tenaga kerja Indonesia untuk bekerja di dalam negeri berkurang bahkan dapat menutup peluang tenaga kerja Indonesia untuk bekerja dan berkarya di negara sendiri. Hal ini menjadi dilema dan dapat menganggu persatuan dan kedaulatan Negara Kesatuan Republik Indonesia.

Kebijakan pemerintah menerbitkan Perpres Nomor 20 Tahun 2018 tersebut menjadi kontradiksi dan tidak sejalan dengan apa yang di amanatkan oleh Undang-Undang Dasar Negara Republik Indonesia Tahun 1945, Pasal 27 ayat (2) yang menetapkan bahwa "tiap-tiap warga negara berhak atas pekerjaan dan penghidupan yang layak bagi kemanusian". Ketentuan tersebut, jelas menghendaki agar semua warga negara Indonesia yang mau dan mampu bekerja supaya diberikan pekerjaan, sekaligus dengan pekerjaan tersebut agar mereka dapat hidup layak sebagai manusia yang mempunyai hak-hak yang dilindungi oleh hukum bukan malah membuka lebar peluang tenaga kerja asing untuk bekerja di negara Indoensia melalui penerbitan regulasi. ${ }^{1}$

Mencermati penomena seperti ini, pemerintah harus secara bijak mengambil sikap yang tidak saja mengikuti perkembangan ekonomi secara global tetapi juga memperhatikan akibat yang

1 Zaeni Ashhadie, Hukum Kerja, Hukum Ketenagakerjaan Bidang Hubungan Kerja, Jakarta:Raja Grapindo Persada, 2008, h. 213 
ditimbulkan dan regulasi tersebut dengan cara memperhatikan kedaulatan negara dan kemanfaatan peraturan perundangundangan di bidang ketenagakerjaan dengan tetap berporos pada hak konstitusional warga Negara melalui regulasi. Efisien dalam konteks berdaya guna, tepat sasaran sehingga mencapai keberhasilam maksimum dalam suatu tindakan dalam keadaan kompetitif. Pembentukan Peraturan Presiden No. 20 Tahun 2018 tentang Penggunaan Tenaga Kerja Asing (Perpres TKA) perlu dikaji lebih lanjut kemanfaatan dan ke efisienan keberadaan Perpres tersebut.

\section{Rumusan Masalah}

Berdasarkan pada uraian latar belakang di atas, maka isu hukum yang dapat ditarik dalam penelitian ini adalah sebagai berikut:

1. Efektivitas dan urgensinya penggunaan Tenaga Kerja Asing di Indonesia.

2. Implikasi penggunaan Tenaga Kerja Asing di Indonesia terhadap kedaulatan dan keutuhan Negara Kesatuan Republik Indonesia.

\section{Metode Penelitian}

Penelitian ini merupakan suatu penelitian hukum, sehingga metode yang digunakan adalah metode penelitian hukum yang dilakukan untuk mencari pemecahan masalah atas 
isu hukum dan permasalahan hukum yang ada, sehingga hasil dari penelitian hukum ini adalah memberikan preskripsi mengenai apa yang seyogyanya mengenai isu hukum yang diajukan serta dapat diterapkan dalam praktek hukum pemerintahan dan keteagakerjaan

\section{Pendekatan Penelitian}

Pendekatan yang digunakan dalam penelitian hukum adalah pendekatan perundang-undangan (statute approach) dan pendekatan konseptual (conceptual approach). ${ }^{2}$

Pendekatan perundang-undangan (statute approach) diperlukan guna mengkaji lebih lanjut mengenai aspek hukum ketenagakerjaan terhadap penggunaan tenaga kerja asing di indonesia dan implikasinya terhadap kedaulatan negara.

Pendekatan konseptual (conceptual approach), digunakan untuk mengkaji dan menganalisis kerangka pikir atau kerangka konseptual maupun landasan teoritis sesuai dengan tujuan penelitian ini yakni menjelaskan hakikat dan batasan prinsip penggunaan tenaga kerja asing di indonesia dan implikasinya terhadap kedaulatan negara. Oleh karena itu perlu dikemukakan tentang teori tenaga kerja dan teori kedaulatan serta teori-teori lainnya yang relevan.

2 Peter Mahmud Marzuki, Penelitian Hukum, Cet. 6, Kencana Prenada Media Group, Jakarta, 2010, hal. 35 


\section{Sumber Bahan Hukum}

Bahan-bahan penelitian berupa bahan hukum primer dan bahan hukum sekunder. Bahan Hukum Primer yang digunakan dalam Penelitian ini antara lain Undang-Undang Dasar Negara Republik Indonesia Tahun 1945; Undang-Undang Nomor 13 Tahun 2003 tentang Ketenagakerjaan; Peraturan Presiden (Perpres) Nomor 20 Tahun 2018 Tentang Penggunaan Tenaga Kerja Asing di Indonesia.

Bahan hukum sekunder meliputi bahan-bahan yang mendukung bahan hukum primer seperti buku-buku teks khusunya buku-buku tentang ketenagakerjaan, buku-buku tentang kedaulatan negara, kamus hukum, artikel dalam berbagai majalah dan jurnal ilmiah bidang hukum, dan sumber lainnya yang mendukung.

\section{Hasil Penelitian Dan Pembahasan}

\section{Efektivitas Dan Urgensinya Penggunaan Tenaga Kerja} Asing Di Indonesia

Tenaga kerja asing sebenarnya dapat ditinjau dari segala segi, dimana salah satunya yang menentukan kontribusi terhadap negara atau perkembangan negara. Tenaga kerja asing adalah tiap orang bukan warga negara Indonesia yang mampu melakukan pekerjaan, baik di dalam maupun di luar hubungan kerja, guna 


\section{Justiciabelen Vol 1 No 1 (2018)}

menghasilkan jasa atau barang untuk memenuhi kebutuhan masyarakat (Abdul Khakim, 2009).

Pengertian tenaga kerja asing ditinjau dari segi undangundang dalam artian pengertian secara otentik, yang telah dijelaskan pada Pasal 1 angka 13 Undang-Undang Nomor 13 Tahun 2003 Tentang Ketenagakerjaan yang menyebutkan bahwa: "Tenaga kerja asing adalah warga negara asing pemegang visa dengan maksud bekerja di wilayah Indonesia. Sedangkan menurut Pasal 1 angka 1 Peraturan Presiden Nomor 20 Tahun 2018 Tentang penggunaan tenaga kerja asing menyebutkan bahwa tenaga kerja asing adalah warga negara asing pemegang visa dengan maksud bekerja di wilayah Indonesia.

Sementara itu, Visa yang selanjutnya disebut Vitas adalah keterangan tertulis yang diberikan oleh pejabat yang berwenang di Perwakilan Republik Indonesia atau di ditempat lain yang ditetapkan oleh Pemerintah Republik Indonesia yang memuat persetujuan bagi Orang asing untuk melakukan perjalanan ke wilayah Indonesia dan menjadi dasar untuk pemberian izin tinggal terbatas dalam rangka bekerja.

Lebih lanjut, Tenaga Kerja Asing, melalui pemberi kerja harus menyampaikan data calon tenaga kerja asing kepada menteri atau pejabat yang ditunjuk, yang meliputi: a). nama, jenis kelamin, tempat dan tanggal lahir; b). kewarganegaraan, nomor paspor, masa berlaku paspor, dan tempat paspor diterbitkan: c). nama jabatan, dan jangka waktu bekerja: d). pernyataan penjaminan dari 
pemberi kerja Tenaga Kerja Asing; dan e). ijazah pendidikan dan surat keterangan pengalaman kerja atau sertifikat kompetensi sesuai dengan syarat jabatan yang akan diduduki tenaga kerja asing.

Keberadaan tenaga kerja asing di Indonesia bukan merupakan sesuatu hal yang baru melainkan sudah menjadi bagian dari sistem perindustrian, perekonomian dan perdagangan Indonesia. Berkaitan dengan keberadaan tenaga kerja asing yang terdapat di Indonesia, Pemerintah telah menerbitkan regulasi terbaru yakni Peraturan Presiden Nomor Nomor 20 Tahun 2018 Tentang Penggunaan Tenaga Kerja Asing. Dimana penggunaan tenaga kerja asing dilaukan oleh pemberi kerja Tenaga Kerja Asing dalam hubungan kerja untuk jabatan tertentu dan waktu tertentu, yang dilakukan dengan memperhatikan kondisi pasar tenaga kerja dalam negeri.

Setiap pemberi kerja Tenaga Kerja Asing wajib mengutamakan penggunaan tenaga kerja Indonesia pada semua jenis jabatan yang tersedia. Dalam hal jabatan sebagaimana dimaksud belum dapat diduduki oleh tenaga kerja Indonesia, jabatan tersebut dapat didudki oleh Tenaga Kerja Asing. Lebih lanjut, pemberi kerja tenaga kerja asing pada sektor tertentu dapat mempekerjakan tenaga kerja asing yang sedang dipekerjakan oleh pemberi kerja tenaga kerja asing yang lain dalam jabatan yang sama, paling lama sampai dengan berakhirnya masa kerja Tenaga Kerja Asing 
sebagaimana kontrak kerja Tenaga Kerja Asing dengan pemberi Kerja Tenaga Kerja Asing pertama.

Pemberi kerja Tenaga Kerja Asing yang akan memperkerjakan Tenaga Kerja Asing menyampaikan data calon Tenaga Kerja Asing kepada meneteri atau pejabat yang ditynjuk, yang meliputi: a). nama, jenis kelamin, tempat dan tanggal lahir; b). Kewarganegaraan, nomor paspor, masa berlaku paspor, dan tempat paspor diterbitkan; c). Nama, jabatan dan jangka waktu bekerja; d). pernyataan penjaminan dari pemberi kerja tenaga kerja asing, dan e). Ijazah pendidikan dan surat keterangan pengalaman kerja atu sertifikat kompetensi sesuai dengan syarat jabatan yang akan diduduki tenaga kerja asing.

Mempekerjakan Tenaga Kerja Asing adalah suatu hal yang ironi dan dilematis, sementara di dalam negeri masih banyak masyarakat yang menganggur. Akan tetapi, karena beberapa sebab dan alasan mempekerjakan Tenaga Kerja Asing tersebut tidak dapat dihindarkan. Ada beberapa tujuan penempatan Tenaga Kerja Asing di Indonesia, yaitu (Budiono, 1995): a). Memenuhi kebutuhan tenaga kerja terampil dan professional pada bidangbidang tertentu yang belum dapat diisi oleh Tenaga Kerja Indonesia; b). Mempercepat Proses pembangunan nasional dengan jalan mempercepat proses alih teknologi atau alih ilmu pengetahuan, terutama di bidang industri; c). Memberikan perluasan kesempatan kerja bagi Tenaga Kerja Indonesia; d). 
Meningkatkan investasi asing sebagai penunjang modal pembangunan di Indonesia.

Tujuan penggunaan tenaga kerja asing tersebut adalah untuk memenuhi kebutuhan tenaga kerja yang terampil dan professional pada bidang tertentu yang belum dapat diduduki oleh tenaga kerja lokal serta sebagai tahapan dalam mempercepat proses pembangunan nasional maupun daerah dengan jalan mempercepat alih ilmu pengetahuan dan teknologi dan meningkatkan investasi asing terhadap kehadiran Tenaga Kerja Asing sebagai penunjang pembangunan di Indonesia walaupun pada kenyataannya perusahaan-perusahaan yang ada di Indonesia baik itu perusahaanperusahaan swasta asing ataupun swasta nasional wajib menggunakan tenaga ahli bangsa Indonesia sendiri (HR. Abdussalam, 2008).

Tujuan pengaturan mengenai tenaga kerja asing jika ditinjau dari aspek hukum ketenagakerjaan pada dasarnya adalah untuk menjamin dan memberi kesempatan kerja yang layak bagi warga negara Indonesia di berbagai lapangan dan tingkatan. Sehingga dalam mempekerjakan tenaga kerja asing di Idonesia harus dilakukan melalui mekanisme dan prosedur yang ketat dumulai dengan seleksi dan prosedur perizinan hingga pengawasan (Agusmidah, 2010).

Masuknya TKA ke Indonesia menjadi konsekuensi atas meningkatnya invstasi PMA di Indonesia. Perpres 20 tahun 2018 ini memunculkan kekawatiran terjadinya ledakan TKA di sektor- 
sektor industri tertentu sehingga mengurangi penyerapan tenaga kerja nasional. Efektivitas perpres teruji ketika berhasil mengatur dan mengawasi penggunaan TKA dan bukan untuk memberi celah dan membiarkan masuknya TKA, serta terjadinya lonjakan investasi PMA di akhir tahun 2018.

Setidaknya ada empat hal yang perlu serius dicermati dari perpres ini. Pertama, apresiasi kepada pemerintah atas integrasi perijinan TKA sehingga lebih mudah dan cepat melalui perpres ini, namun perlu dicermati hal perluasan klasul 'badan usaha sepanjang tidak dilarang oleh Undang-Undang' ini. Badan usaha ini harus diperjelas wujudnya dan apa bedanya dengan badan hukum yang sudah ada. Badan usaha ini tidak boleh menjadi celah untuk memudahkan masuknya TKA ke sektor-sektor investasi tertentu dari hulu sampai hilir. ${ }^{3}$

Kedua, tidak menjadikan dana kompensasi penggunaan TKA ini sebagai penambah PNBP. Jika diasumsikan per tahun masuk 100 ribu TKA baru dan perpanjangan 50 ribu TKA, maka PNBP bisa meraup lebih dari Rp 2,4 triliun per tahun. Di satu sisi ada peningkatan PNBP, namun menggerus penyerapan tenaga kerja dalam negeri. ${ }^{4}$

Ketiga, agar pemerintah menerapkan batasan penggunaan TKA (TKA Threshold) maksimal 20 persen pada proyek

\footnotetext{
${ }^{3}$ https://www.republika.co.id/berita/kolom/wacana/18/04/12/p72tpv396 -mempertanyakan-efektivitas-perpres-202018. Di akses pada tanggal 6 Agustus 2018.

${ }^{4}$ Ibid
} 
pembangunan investasi PMA terutama di daerah-daerah dengan peraturan menteri. Hal ini akan menaikkan daya serap tenaga kerja dalam negeri. ${ }^{5}$

Keempat, mendesak kementerian luar negeri khususnya dirjen imigrasi melakukan pengawasan lebih ketat terhadap exit permit TKA yang telah habis kontrak dan exit wisatawan manca negara dari imigrasi Indonesia. Dengan pengawasan ini diharapkan menghilangkan penyerapan TKA illegal. ${ }^{6}$

Menurut Budiono, ada beberapa tujuan penempatan TKA di Indonesia, yaitu: ${ }^{7}$

1. Memenuhi kebutuhan tenaga kerja terampil dan profesional pada bidang- bidang tertentu yang belum dapat diisi oleh TKI.

2. Mempercepat proses pembangunan nasional dengan jalan mempercepat proses alih teknologi atau alih ilmu pengetahuan, terutama di bidang industri.

3. Memberikan perluasan kesempatan kerja bagi TKI.

4. Meningkatkan investasi asing sebagai penunjang modal pembangunan di Indonesia.

\section{${ }^{5}$ Ibid}

${ }^{6}$ Ibid

${ }^{7}$ Budiono, Abdul Rachmat, Hukum Perburuhan Di Indonesia, (Jakarta: PT. Rajagrafindo Persada, 1995), h. 115. 
Dasar hukum yang mengatur mengenai penggunaan tenaga kerja asing dan ijin memperkerjakan tenaga kerja asing (IMTA) adalah sebagai berikut:

1. Undang-undang Nomor 13 Tahun 2003 Tentang Ketenagakerjaan yang tercantum pada Pasal 1 Angka 13, Pasal 1 Angka 32 mengenai pengertian Tenaga Kerja Asing (TKA) dan pengertian pengawasan ketenagakerjaan; Pasal 43 mengenai Rencana Penggunaan Tenaga Kerja Asing.

2. Peraturan Meteri Tenaga Kerja dan Transmigrasi Republik Indonesia Nomor 12 Tahun 2013 Tentang Tata Cara Penggunaan Tenaga Kerja Asing yang tercantum pada Pasal 1 Angka 1, Pasal 1 Angka 4, Pasal 1 Angka 5, Pasal 1 Angka 11, Pasal 1 Angka 13, Pasal 1 Angka 15 mengenai Pengertian Tenaga Kerja Asing (TKA), Rencana Penggunaan Tenaga Kerja Asing (RPTKA), Ijin Memmpekerjakan Tenaga Kerja Asing (IMTA), Menteri Tenaga Kerja \& Transmigrasi, Direktur Pengendalian Penggunaan Tenaga Kerja Asing, Dinas Kabupaten/Kota yang bertanggung jawab di bidang ketenagakerjaan kab/kota; Pasal 3 mengenai Pemberi kerja TKA; Pasal 7 mengenai Pengesahan Rencana Penggunaan Tenaga Kerja Asing RPTKA ); Pasal 30 mengenai Tata cara permohonan IMTA. 
3. Peraturan Pemerintah Republik Indonesia Nomor 97 Tahun 2012 tentang Retribusi Pengendalian Lalu Lintas \& Perpanjangan Izin Mempekerjakan tenaga Kerja Asing yang tercantum pada Pasal 1 Angka 1, Pasal 1 Angka 3, Pasal 1 Angka 4, Pasal 1 Angka 5 mengenai pengertian retribusi daerah, retribusi perpanjangan IMTA, perpanjangan IMTA, pengertian Tenaga Kerja Asing (TKA); Bab IV Pasal 15 Peraturan Pemerintah Republik Indonesia Nomor 97 Tahun 2012 tentang Retribusi Pengendalian Lalu Lintas \& Perpanjangan Izin Mempekerjakan tenaga Kerja Asing yang mengatur mengenai besarnya tarif Retribusi IMTA yang ditetapkan dengan peraturan daerah; Pasal 16 mengenai penerimaan Retribusi IMTA serta pemanfataanya.

4. Peraturan Presiden Nomor 20 Tahun 2018 tentang Penggunaan Tenaga Kerja Asing di Indonesia.

Secara umum TKA yang berada di Indonesia dikategorikan pada 2 (dua) kategori, yaitu: ${ }^{8}$

1. TKA legal (memiliki dokumen resmi); hal ini mengacu pada ketentuan umum UU No. 6/2011 tentang keimigrasian, Pasal 1 angka:

8 https://www.google.co.id/search?safe=strict\&hl=en\&ei=VvhnWq5EoP79QP hLSIBw\&q=aspek+hukum+penggunaan+tenaga+kerja+asing $+\mathrm{di}+\mathrm{i}$ ndonesia. Di akses pada tanggal 7 Agustus 2018. 
(13) Dokumen Perjalanan adalah dokumen resmi yang dikeluarkan oleh pejabat yang berwenang dari suatu negara, Perserikatan Bangsa-Bangsa, atau organisasi internasional lainnya untuk melakukan perjalanan antarnegara yang memuat identitas pemegangnya.

(14) Dokumen Keimigrasian adalah Dokumen Perjalanan Republik Indonesia, dan Izin Tinggal yang dikeluarkan oleh Pejabat Imigrasi atau pejabat dinas luar negeri.

Dengan demikian, supaya dapat keluar masuk wilayah Indonesia maka setiap orang asing termasuk di dalamnya TKA diwajibkan memiliki Dokumen Perjalanan (Paspor dan Surat Perjalanan Laksana Paspor) yang sah dan masih berlaku serta memiliki Visa yang sah dan masih berlaku, kecuali ditentukan lain berdasarkan Undang-Undang ini dan perjanjian internasional. ${ }^{9}$

Pemberian Visa TKA adalah visa tinggal terbatas (Pasal 39) termasuk juga rohaniawan, tenaga ahli, peneliti, pelajar, investor, lanjut usia, dan keluarganya, serta Orang Asing yang kawin secara sah dengan warga negara Indonesia, yang akan melakukan perjalanan ke Wilayah Indonesia untuk bertempat tinggal dalam jangka waktu yang terbatas; atau dalam rangka bergabung untuk bekerja di atas kapal, alat apung, atau instalasi

\footnotetext{
${ }^{9}$ Lihat ketentuan Pasal 8 Ayat (1) dan (2) UU Kemigrasian.
} 
yang beroperasi di wilayah perairan nusantara, laut teritorial, landas kontinen, dan/atau Zona Ekonomi Eksklusif Indonesia.

2. TKA Illegal (tanpa dokumen resmi)

Pemberi kerja dapat memperkerjakan TKA untuk bekerja di Indonesia. Namun, jika penggunaan TKA tidak mengikuti aturan yang telah ditetapkan oleh Undang-Undang Nomor 13 Tahun 2003 tentang Ketenagakerjaan berarti telah memperkerjakan TKA ilegal. Penggunaan TKA ilegal merupakan hal yang melanggar hukum dan dapat menimbulkan akibat hukum berupa sanksi pidana. Sanksi pidana dapat dikenakan kepada TKA maupun kepada pemberi kerja yang telah mempekerjakan orang asing yang melanggar ketentuan Pasal 185 Undang-Undang Nomor 13 Tahun 2003 tentang Ketenagakerjaan, menyatakan:

(1) Barang siapa melanggar ketentuan sebagaimana dimaksud dalam Pasal 42 Ayat (1) dan Ayat (2), Pasal 68, Pasal 69 Ayat (2), Pasal 80, Pasal 82, Pasal 90 ayat (1), Pasal 143, dan Pasal 160 Ayat (4) dan Ayat (7), dikenakan sanksi pidana penjara paling singkat 1 (satu) tahun dan paling lama 4 (empat) tahun dan/atau denda paling sedikit Rp 100.000.000,00 (seratus juta rupiah) dan paling banyak Rp 400.000.000,00 (empat ratus juta rupiah). (2) Tindak pidana sebagaimana dimaksud dalam Ayat (1) merupakan tindak pidana.

Dengan demikian, pemberi kerja yang akan menggunakan 
TKA wajib memiliki izin tertulis dari menteri atau pejabat yang ditunjuk dan pemberi kerja orang perseorang dilarang memperkerjakan TKA sebagaimana diatur dalam Pasal 42 Ayat (1) dan (2) Undang-Undang Nomor 13 Tahun 2003 tentang Ketenagakerjaan dan bila melanggar ketentuan penggunaan TKA yang diatur dalam Undang- Undang Nomor 13 Tahun 2003 Tentang Ketenagakerjaan maka akan dikenakan sanksi pidana. ${ }^{10}$

Oleh karena itu, pemberi kerja tenaga kerja asing wajib mengajukan Rencana Penggunaan Tenaga Kerja Asing (RPTKA) untuk memperoleh Izin Memperkerjakan Tenaga Kerja Asing (IMTA) serta bersedia untuk dikenakan retribusi. Di sisi lain pemerintah juga tidak dapat menutup mata, di mana situasi dan kondisi Indonesia masih belum dapat menciptakan lapangan kerja bagi sebagian dari pencari kerja. ${ }^{11}$ Pemberian izin penggunaan tenaga kerja asing dimaksudkan agar pengguna tenaga kerja asing dilaksanakan secara selektif dalam rangka pemberdayaan tenaga kerja lokal secara optimal. ${ }^{12}$

Oleh karena itu di dalam mempekerjakan tenaga kerja asing, dilakukan melalui mekanisme dan prosedur yang sangat ketat, terutama dengan cara mewajibkan bagi perusaahan yang mempergunakan tenaga kerja asing bekerja di wilayah Indonesia dengan membuat rencana penggunaan tenaga kerja asing (RPTKA)

\footnotetext{
${ }^{10}$ Op.Cit., h. 96.

${ }^{11}$ Ibid

${ }^{12}$ Ibid
} 
yang sebagaimana diatur dalam Peraturan Menteri Tenaga Kerja dan Transmigrasi RepublikIndonesia Nomor 12 Tahun 2013 Tentang Tata Cara Penggunaan Tenaga Kerja Asing.

Dalam ketentuan Pasal 71 UU Keimigrasian disebutkan bahwa setiap Orang Asing yang berada di Wilayah Indonesia wajib:

a. memberikan segala keterangan yang diperlukan mengenai identitas diri dan/atau keluarganya serta melaporkan setiap perubahan status sipil, kewarganegaraan, pekerjaan, Penjamin, atau perubahan alamatnya kepada Kantor Imigrasi setempat; atau

b. memperlihatkan dan menyerahkan Dokumen Perjalanan atau Izin Tinggal yang dimilikinya apabila diminta oleh Pejabat Imigrasi yang bertugas dalam rangka pengawasan Ke-imigrasian.

Jika kewajiban tersebut tidak dilaksanakan maka berdasarkan Pasal 116 akan dipidana dengan pidana kurungan paling lama 3 (tiga) bulan atau pidana denda paling banyak Rp 25.000.000,00 (dua puluh lima juta rupiah).

2. Implikasi Penggunaan Tenaga Kerja Asing Di Indonesia Terhadap Kedaulatan Dan Keutuhan Negara Kesatuan Republik Indonesia

Kedaulatan merupakan kekuasaan absolute atas suatu wilayah tertentu. Kekuasaan absolute atas wilayah tersebut menjadi dasar bagi pembentukan negara (Jenik Radon, 2004). 
Kedaulatan negara adalah kekuaasan tertinggi yang dimiliki suatu negara untuk menguasai wilayah pemerintahnnya dan masyarakat. Kekuasaan tersebut bersifat asli tunggal dan tidak terbatas. Kedaulatan yang ada pada negara, negaralah yang menciptakan hukum, jadi segala sesuatu harus tunduk kepada negara. Negara disini dianggap sebagai suatu keutuhan yang menciptkan peraturan-peraturan hukum, jadi dengan hukum itu karena adanya negara dan tiada satu hukumpun yang berlaku jika tidak dikehendaki oleh negara.

Dalam hal ini dapat ditegaskan bahwa secara tidak langsung negara yang baik adalah mencerminkan kedaulatan rakyat, karena kehendak individu harus tunduk dengan kehendak umum.

Suatu negara harus memiliki pemerintah, baik seorang atau beberapa orang yang mewakili warganya sebagai badan politik serta hukum dinegaranya, dan pertahanan wilayah negaranya. Pemerintah dengan kedaulatan yang dimilikinya merupakan penjamin stabilitas internal dalam negaranya, disamping juga untuk menjamin kemampuan untuk memenuhi kewajibannya dalam pergaulan internasional. Pemerintah inilah yang mengeluarkan kebijakan-kebijakan dalam rangka mencapai kepentingan nasional negaranya, baik itu di dalam negaranya, dalam rangka mempertahankan integritas negaranya, maupun di 
luar negaranya melaksanakan politik luar negeri untuk suatu tujuan tertentu. ${ }^{13}$

Disini dapat disimpulkan bahwa kedaulatan juga merupakan symbol kehormatan negara, jika ada negara yang kedaulatannya terciderai oleh negara lain maka bisa saja akan menimbulkan peperangan yang berpotensi banyaknya nyawa yang hilag. Pentingnya kedaulatan bagi negara maka banyak negara yang rela mengalokasikan kas negara untuk membeli atau memproduksi peralatan tempur lainnya serta memperbanyak anggota militer. ${ }^{14}$

Salah satu masalah yang dapat menganggu kedaulatan negara adalah masalah ekonomi suatu negara. Masalah ekonomi dewasa ini sering sekali menjadi perbincangan lintas negara bagaimana cara meningkatkan perekonomian suatu bangsa. Salah satu cara untuk menigkatkan ekonomi suatu negara adalah dengan cara memperkerjakan orang asing di dalam negeri dengan dalil dapat menimbulkan alih teknologi dan lain sebagainya. Akan tetapi tentu kebijakan ini sangat berisiko terhadap terciptanya lapangan pekerjaan untuk masyarakat dalam negeri.

Pertumbuhan ekonomi riil yang kurang optimal akan meredam prospek pertumbuhan lapangan pekerjaan. Selain itu, upah riil yang stagnan di banyak negara juga mempengaruhi

${ }^{13}$ Muhammad Junaidi, Ilmu Negara Sebuah Konstruksi Ideal Negara Hukum, Malang:Setara Press, 2016, h. 113.

${ }^{14}$ Ibid., h. 117 
pertumbuhan ekonomi ini terutama pertumbuhan ekonomi Indonesia. Memperhatikan situasi dan kondisi terutama di bidang pekerjaan ataupun kesempatan kerja yang semakin sempit dan sulit bahkan tak mampu lagi menanpung pekerja yang bertambah setiap tahun. Ironisnya, ditengah kondisi seperti itu, makin marak dan besarnya tenaga kerja asing yang masuk ke Indonesia. Selain akibat perlambatan ekonomi yang merupakan imbas kritis ekonomi global, tingginya pengangguran di Indonesia merupakan dampak dari simtem kapitalisme dan regulasi yang diterapkan (diberlakukan) yang di adopsi dan digunakan negara Indonesia.

Berdasarkan pada ketentuan Undang-Undang Nomor 13 Tahun 2003 tentang Ketenagakerjaan, tenaga kerja asing adalah warga negara asing pemegang visa dengan maksud bekerja di wilayah Indonesia. Lebih lanjut, dalam ketentuan Undang-Undang Ketenagakerjaan tersebut, juga menegaskan ketentuan bahwa setiap pengusaha dilarang mempekerjakan orang-orang asing tanpa izin tertulis dari meneri atau pejabat yang ditunjuk.

Di era globalisasi ini, pekerja antar negara dibuat mudah. Sebab itulah tenaga kerja asing pun bisa masuk ke Indonesia. Kehadiran tenaga kerja asing di Indonesia dapat berimbas pada kesempatan kerja yang dimiliki oleh tenaga kerja Indonesia sendiri (Lalu Husni, 2000). Sebab dengan kehadiran tenaga kerja asing dapat menyebabkan kelangkaan lapangan pekerjaan bagi penduduk dalam negeri. Selain itu, dapat menyebabkan kedaulatan negara dapat terpecahkan melalui tidak utuh dan sejahteranya 
perekonomian Indonesia. Tentu hal ini sebagai pekerjaan rumah untuk pemerintah Indonesia supaya dapat menyelaraskan antara pertumbuhan ekonomi dan kedaulatan negara dengan tidak mengorbankan rakyat sendiri.

Hal ini memang menjadi berat, sebab pemerintah dihadapkan pada pilihan yang sangat sulit. Satu sisi pemerintah ingin meningkatka perekonomian rakyat di sisi lain harus mengorbankan rakyat sendiri. Adanya kebijakan pemerintah yang menerbitkan Perpres Nomor 20 Tahun 2018 tersebut lagi-lagi menjadikan pemerintah dihadapkan pada dua pilihan kepentingan yang berbeda-beda dan masing-masing harus diperhatikan dan dipertimbangkan. Di satu pihak, kebutuhan akan peningkatan investasi dan pendapatan negara serta alih pengetahuan dan teknologi dengan penggunaan tenaga kerja asing, di lain pihak pemerintah menjadi ironi, sebab dengan kehadiran tenaga kerja asing, maka secara otomatis peluang/kesempatan bekerja bagi penduduk Indonesia semakin sempit dan sulit.

Penggunaan Tenaga Kerja Asing mungkin saja memiliki dampak positif bagi peningkatan perekonomian, investasi, perindustrian, perdagangan dan lainnya di Indonesia, jika memenuhi prosedur dan persyaratan sebagaimana yang telah ditetapkan pemerintah. Akan tetapi ada begitu banyak dampak negatif yang akan ditimbulkan, karena seperti yang kita ketahui terkadang aturan sering sekali tidak sesuai dengan praktiknya di lapangan. Pemerintah tampaknya keliru dalam menganalisa dan 
membaca akar masalah yang terdapat di Indonesia. Demi mendongkrak investasi besar, apabila investor mensyaratkan masukanya Tenaga Kerja Asing, maka itu dipermudah tanpa memikirkan resikonya bagi rakyat sendiri. Padahal akar masalah investasi bukan pada adanya kendala bahasa pada Tenaga Kerja Asing yang akan masuk melainkan kurangnya skil dalam negeri dan penciptaan lapangan pekerjaan serta kesempatan kerja oleh pemerintah Indonesia.

\section{Kesimpulan}

Berdasarkan hasil penelitian dan analisis yang dilakukan melalui pengkajian sebagaimana yang telah diuraikan dalam babbab sebelumnya, maka penelitian ini sampai pada kesimpulan sebagai berikut:

1. Efektivitas dan urgensinya penggunaan Tenaga Kerja Asing di Indonesia sangat efektif dan urgen untuk memenuhi kebutuhan tenaga kerja yang terampil dan professional pada bidang tertentu yang belum dapat diduduki oleh tenaga kerja lokal serta sebagai tahapan dalam mempercepat proses pembangunan nasional maupun daerah dengan jalan mempercepat alih ilmu pengetahuan dan teknologi dan meningkatkan investasi asing terhadap kehadiran Tenaga Kerja Asing sebagai penunjang pembangunan di Indonesia walaupun pada kenyataannya perusahaan-perusahaan yang ada di Indonesia baik itu perusahaan-perusahaan swasta asing ataupun swasta 
nasional wajib menggunakan tenaga ahli bangsa Indonesia sendiri.

Tujuan pengaturan mengenai tenaga kerja asing jika ditinjau dari aspek hukum ketenagakerjaan pada dasarnya adalah untuk menjamin dan memberi kesempatan kerja yang layak bagi warga negara Indonesia di berbagai lapangan dan tingkatan. Sehingga dalam mempekerjakan tenaga kerja asing di Idonesia harus dilakukan melalui mekanisme dan prosedur yang ketat dumulai dengan seleksi dan prosedur perizinan hingga pengawasan.

2. Implikasi penggunaan Tenaga Kerja Asing di Indonesia terhadap kedaulatan dan keutuhan Negara Kesatuan Republik Indonesia tidak dapat menimbulkan terganggunya kedaulatan negara, hanya saja dapat berimbas pada kesempatan kerja yang dimiliki oleh tenaga kerja Indonesia sendiri menjadi berkurang dan langka. Sebab dengan kehadiran tenaga kerja asing dapat menyebabkan kelangkaan lapangan pekerjaan bagi penduduk dalam negeri. Penggunaan Tenaga Kerja Asing mungkin saja memiliki dampak positif bagi peningkatan perekonomian, investasi, perindustrian, perdagangan dan lainnya di Indonesia, jika memenuhi prosedur dan persyaratan sebagaimana yang telah ditetapkan pemerintah. 


\section{Daftar Pustaka}

Abdussalam, H.R. 2008. Hukum Ketenagakerjaan.Jakarta:Restu Agung.

Agusmidah. 2010. Hukum Ketenagakerjaan Indonesia, Dinamika Dan Kajian Teori.Bogor:Ghalia.

Asyhadie, Zaeni. 2008. Hukum Kerja, Hukum Ketenagakerjaan bidang Hukum Kerja. Jakarta:Rajagrapindo Persada.

Budiono, Abdul Rachmat. 1995. Hukum Perburuhan Di Indonesia. Jakarta:PT.RajaGrapindo Persada.

Husni, Lalu. 2000. Pengantar Hukum Ketenagakerjaan. Jakarta:PT Raja Grapindo Persada.

Junaidi, Muhammad. 2016. Ilmu Negara Sebuah Konstruksi Ideal Negara Hukum, Malang:Setara Press.

Khakim, Abdul. 2009, Dasar-Dasar Hukum Ketenagakerjaan Indonesia. Bandung:Citra Aditya Bakti.

Marzuki, Peter Mahmud Penelitian Hukum, Cet. 6, Kencana Prenada Media Group, Jakarta, 2010

Radon, Jenik. 2004. "Sovereignty: A Political Emotion, Not A Concept". (40.) Stanford Journal of International Law. Commemorative Issue: Balance of Power: Redefining Sovereignty in Contemporary International Law Commemorative Introduction, Summer 2004. Stanford: University of Stanford. 
https://mediaumat.news/menyoal-peraturan-presiden-perpresnomor-20-tahun-2018-rakyat-untung-atau-buntung/. Di akses pada tanggal 3 Mei 2018.

http://republika.co.id/berita/ekonomi/korporasi/18/04/05/p6pl2h37

7jokowi-tandatangani-perpres-kemudahan-pekerja-asing. Di akses pada tanggal 3 Mei 2018

http://setkab.go.id/inilah-perpres-nomor-20-tahun-2018-tentang penggunaan-tenaga-kerja-asing/.Di akses pada tanggal $5 \mathrm{Mei}$ 2018

https://www.republika.co.id/berita/kolom/wacana/18/04/12/p72tpv 396-mempertanyakan-efektivitas-perpres-202018. Di akses pada tanggal 6 Agustus 2018.

https://www.google.co.id/search?safe=strict\&hl=en\&ei=VvhnWq5EoP79QP_hLSIBw\&q=aspek+hukum+penggunaan+tenag a+kerja+asing+di+indonesia.. Di akses pada tanggal 7 Agustus 2018. 